\title{
Pedogenetic characterization and classification of forest soils in the Central Middle Atlas (Morocco)
}

\author{
Mohamed El Mderssa a,*, Hassan Benjelloun b, Omar Zennouhi a \\ Laila Nassiri a, Jamal Ibijbijen a \\ a Faculty of Sciences, Moulay Ismail University, Zitoune-Meknes, Morocco \\ b National School of Forest Engineers, Sale-Tabriquet, Morocco
}

\section{Article Info}

Received : 18.11 .2018

Accepted : 15.03 .2019

\begin{abstract}
The study was carried out in the forests of the Central Middle Atlas where the soils have a Mediterranean character. The forest formations found include resinous species such as on Atlas cedar (Cedrus atlantica) and maritime mountain pine (Pinus pinaster), and deciduous species of green oak (Quercus rotundifolia) and zeen oak (Quercus canariensis). The morphological description of soils' genetic horizons was based on the opening of soil pedons in the forest formations composing the studied area. Then, physical and chemical characterization of the studied soils was analyzed. According to the Commission of Pedology and Soil Mapping (CPCS, 1967) principles and those of the international system of classification, nomenclature and soil mapping used by FAO (2015), three types of soils were identified as dominant in these forests, namely, the class of browned soils, iron sesquioxide soils and calcimagnesic soils. As a result, they differ in their responses to management practices, their inherent ability to deliver ecosystem services, as well as their resilience to disturbance and vulnerability to degradation.
\end{abstract}

Keywords: Browned soils, Calcimagnesics, Middle Central Atlas, iron sesquioxide.

(C) 2019 Federation of Eurasian Soil Science Societies. All rights reserved

\section{Introduction}

Forests and forest soils have been performing essential, complex and interactive functions in the environment for millions of years, soils support trees and forests. Soils are a major component of forests and forest ecosystems because they help to regulate important ecosystem processes, such as the absorption of nutrients, the decomposition of organic matter and the availability of water. They provide trees with anchorage, water and nutrients (FAO, 2015). On the other hand, forest soils can become an important source of $\mathrm{CO}_{2}$ as a result of global warming, as the latter could lead to mineralization of organic matter higher than the net primary production of vegetation (Bernoux et al., 2005). Even small changes in the organic carbon reservoir in the soil can significantly affect the concentration of $\mathrm{CO}_{2}$ in the atmosphere, since the soil contains twice as much carbon as the atmosphere (Schlesinger, 1977; Post et al. 1982; Watson et al., 1990).

Soil characterization studies are major building block for understanding the soil, classifying it and getting the best understanding of the environment (Onyekanne et al., 2012). Soil characterization provides the information for our understanding of the physical, chemical, and genetic properties of soil. It also helps to organize our knowledge, facilitates the transferring of experience and technology from one place to another (Chekol and Mnalku, 2012; Adhanom and Toshome, 2016). The Characterization and classification of these soils have therefore paramount importance in using those resources based on their capability and to manage them in sustainable manner. The soils of the forests of the Central Middle Atlas are of great importance and

\footnotetext{
${ }^{*}$ Corresponding author.

Faculty of Sciences, Moulay Ismail University B.P. 11201 Zitoune-Meknes, Morocco

Tel.: +212669564586

e-ISSN: 2147-4249
} 
present a variability in their physical and chemical characteristics as well as in the genetic profiles. As a result, they differ in their responses to management practices, their inherent ability to deliver ecosystem services, as well as their resilience to disturbance and vulnerability to degradation (FAO, 2017). The objective of this study is to determine the physical and chemical properties of the genetic horizons of these soils while identifying the dominant soil types in this area.

\section{Material and Methods}

\section{Presentation of the studied area}

This study was carried out in three forests in the Central Middle Atlas, including the forest of Azrou, the forest of Jaaba and the forest of the south of Jbel Aoua (Figure 1). These forests are considered the most important in terms of area and have a diversity of forest composition and lithological material. The Middle Atlas is an intracontinental mountain range oriented NE-SW and extended over about $350 \mathrm{~km}$ that is part of the Atlas domain (Michard, 1976). These forests receive annual rainfall ranging from 800 to $1100 \mathrm{~mm}$. Snowfall occurs sporadically from December to April with variable heights ranging from 20 to $60 \mathrm{~cm}$. The climate in this area is Mediterranean with a bioclimatic atmosphere ranging from sub-humid to cool, to wet and to very cold (HCEFLCD, 2007).

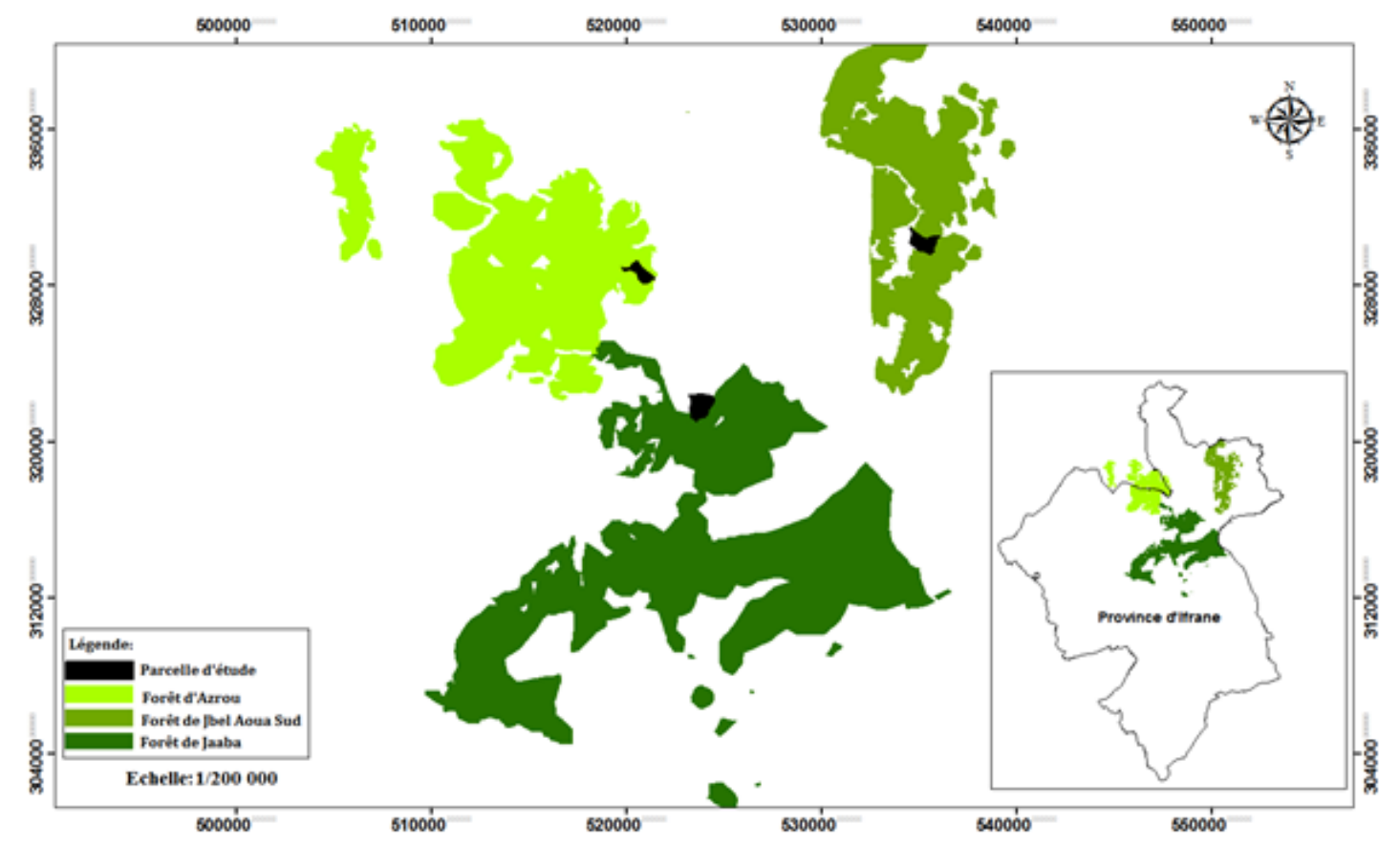

Figure 1. The map of the studied area

\section{Methodological approach}

At the level of each forest, a plot representative of the topoclimatic plan and the type of forest cover occupying the region was chosen to open soil pits. The number of soil profiles prepared at the level of each plot was based on its area and the forest composition present. This approach allowed us to identify nine sites, each of which is the subject of a soil pit (Table 1).

The description of the studied sites focused on the distinction of genetic horizons and their depth, color, texture, structure, consistency, rooting, $\mathrm{pH}$ and transition between horizons.

A $200 \mathrm{~g}$ soil sample was taken from each horizon. After sieving the soil through $2 \mathrm{~mm}$ meshes, physical and chemical analyses were carried out at the Soil Microbiology and Environment Laboratory of the Faculty of Science in Meknes to determine the granulometric composition of the fine soil $(<2 \mathrm{~mm}), \mathrm{pH}$, organic matter (Organic carbon), total nitrogen, assimilable phosphorus, total limestone, cation exchange capacity and base saturation rate. Soil pH was measured in the supernatant suspension of soil using $\mathrm{pH}$ meter. Soil organic carbon was determined using the Walkley and Black wet oxidation method (Walkley and Black, 1934). The organic matter is obtained by multiplying the organic carbon rate by the coefficient of 1.724 (Dabin, 1970). Total nitrogen was determined using the Kjeldahl procedure (Wilke, 2005). Available phosphorus was determined using Olsen method (Olsen and Sommers, 1982). 
Table 1. Description of the identified sites

\begin{tabular}{|c|c|c|c|c|c|c|c|}
\hline $\begin{array}{l}\text { Number } \\
\text { of site }\end{array}$ & Localisation & Coordinates & Exposition & $\begin{array}{r}\text { Slope } \\
(\%)\end{array}$ & $\begin{array}{r}\text { Altitude } \\
(\mathrm{m})\end{array}$ & $\begin{array}{r}\text { Parent } \\
\text { rock }\end{array}$ & $\begin{array}{r}\begin{array}{r}\text { Forest } \\
\text { vegetation }\end{array} \\
\end{array}$ \\
\hline 1 & Jaaba forest & $\begin{array}{r}33^{\circ} 33^{\prime} 7^{\prime \prime} \mathrm{N} \\
-5^{\circ} 10^{\prime} 28^{\prime \prime} \mathrm{W}\end{array}$ & NW & 14 & 1593 & Basalt & $\begin{array}{r}\text { Mixture of an adult forest of zeen } \\
\text { oak and green oak }\end{array}$ \\
\hline 2 & Jaaba forest & $\begin{array}{l}33^{\circ} 33^{\prime} 16^{\prime \prime} \mathrm{N} \\
-5^{\circ} 10^{\prime} 38^{\prime \prime} \mathrm{W}\end{array}$ & $\mathrm{N}$ & 10 & 1562 & Basalt & Mature zen oak forest \\
\hline 3 & $\begin{array}{l}\text { South Jbel } \\
\text { Aoua forest }\end{array}$ & $\begin{array}{l}33^{\circ} 34^{\prime} 26^{\prime \prime} \mathrm{N} \\
-5^{\circ} 01^{\prime} 33^{\prime \prime} \mathrm{W}\end{array}$ & NE & 13 & 1745 & $\begin{array}{l}\text { Sandy } \\
\text { dolomite }\end{array}$ & Mature green oak forest \\
\hline 4 & $\begin{array}{l}\text { South Jbel } \\
\text { Aoua forest }\end{array}$ & $\begin{array}{l}33^{\circ} 34^{\prime} 21^{\prime \prime} \mathrm{N} \\
-5^{\circ} 01^{\prime} 26^{\prime \prime} \mathrm{W}\end{array}$ & $\mathrm{NE}$ & 15 & 1750 & $\begin{array}{r}\text { Sandy } \\
\text { dolomite }\end{array}$ & Young cedar forest \\
\hline 5 & $\begin{array}{l}\text { South Jbel } \\
\text { Aoua forest }\end{array}$ & $\begin{array}{l}33^{\circ} 34^{\prime} 10^{\prime \prime} \mathrm{N} \\
-5^{\circ} 00^{\prime} 54^{\prime \prime} \mathrm{W}\end{array}$ & NE & 18 & 1740 & $\begin{array}{l}\text { Sandy } \\
\text { dolomite }\end{array}$ & Mature maritime pine forest \\
\hline 6 & $\begin{array}{l}\text { South Jbel } \\
\text { Aoua forest }\end{array}$ & $\begin{array}{l}33^{\circ} 34^{\prime} 03^{\prime \prime} \mathrm{N} \\
-5^{\circ} 00^{\prime} 51^{\prime \prime} \mathrm{W}\end{array}$ & NE & 20 & 1768 & $\begin{array}{r}\text { Sandy } \\
\text { dolomite }\end{array}$ & $\begin{array}{r}\text { Mixture of a young green oak forest } \\
\text { and a mature cedar forest }\end{array}$ \\
\hline 7 & Azrou forest & $\begin{array}{l}33^{\circ} 29^{\prime} 57^{\prime \prime} \mathrm{N} \\
-5^{\circ} 08^{\prime} 31^{\prime \prime} \mathrm{W}\end{array}$ & NE & 20 & 1690 & Basalt & Pure cedar forest \\
\hline 8 & Azrou forest & $\begin{array}{l}33^{\circ} 29^{\prime} 34^{\prime \prime} \mathrm{N} \\
-5^{\circ} 08^{\prime} 39^{\prime \prime} \mathrm{W}\end{array}$ & SW & 10 & 1720 & Basalt & Mature zeen oak forest \\
\hline 9 & Azrou forest & $\begin{array}{l}33^{\circ} 29^{\prime} 30^{\prime \prime} \mathrm{N} \\
-5^{\circ} 08^{\prime} 43^{\prime \prime} \mathrm{W} \\
\end{array}$ & SW & 25 & 1710 & Basalt & Mature green oak forest \\
\hline
\end{tabular}

\section{Results and Discussion}

\section{Morphological characteristics}

Table 2 shows the morphological characteristics of the studied soils. They show a fairly homogeneous character of these soils, with the exception of the depth of the horizons which shows some differentiation. The color is a property that is easy to observe and measure, but its interpretation must be made in interference with soil mineralogy, alteration stage, organic matter content, seasonal fluctuations in water and several other aspects of land use and performance (Olson, 1981). This is a very important criterion to study because it provides information on the properties and behaviour of the soil. Indeed, apart from the soil at site no 8 where the red coloration appears from the surface, all other soils have a dark brown coloration in the surface horizons and more reddish at depth. Concerning the structure, it is defined by Plaisance and Cailleux (1958) as the way in which the aggregates are arranged in the ground building. The structure of the studied soils is lumpy everywhere. This fairly stable structure plays an essential role because it maintains the favorable physical properties of the forest soil (aeration and drainage) and also because it prevents any unfavorable pedological evolution of the profile (Duchaufour, 1953).

Table 2. Morphological characteristics of the studied soils

\begin{tabular}{|c|c|c|c|c|c|}
\hline $\begin{array}{l}\text { Number } \\
\text { of site }\end{array}$ & $\begin{array}{l}\text { Depth of the } \\
\text { litter } \mathrm{L}+\mathrm{F}(\mathrm{cm})\end{array}$ & Horizon & Depth (cm) & Moist color & Structure \\
\hline \multirow{3}{*}{1} & \multirow{3}{*}{$0-4$} & A & $0-37$ & 10 YR 2/2, Very dark brown & Lumpy \\
\hline & & $\mathrm{B}_{1}$ & $37-47$ & 7,5 YR 4/6, Intense brown & Irregular lumpy \\
\hline & & $\mathrm{B}_{2}$ & $47-86$ & 7,5 YR 4/6, Intense brown & Regular lumpy and prismatic \\
\hline \multirow{2}{*}{2} & \multirow{2}{*}{$0-4$} & $\mathrm{~A}_{\mathrm{H}}$ & $0-47$ & 7,5 YR 4/6, Intense brown & Irregular lumpy \\
\hline & & $\mathrm{B}$ & $47-85$ & 10 YR 3/6, Dark red & Irregular lumpy \\
\hline \multirow{2}{*}{3} & \multirow{2}{*}{$0-2$} & $\mathrm{~A}$ & $0-60$ & 10 YR 2/2, Very dark brown & Lumpy \\
\hline & & $\mathrm{C}_{\mathrm{R}}$ & $>60$ & - & 40 \\
\hline 4 & \multicolumn{5}{|c|}{ Same as site no. 3} \\
\hline \multirow{2}{*}{5} & \multirow{2}{*}{$0-10$} & A & $0-50$ & 7,5 YR 3/4, Dark brown & Lumpy \\
\hline & & $\mathrm{C}_{\mathrm{R}}$ & $>50$ & - & $8 x^{4}$ \\
\hline 6 & & & & me as site no.5 & \\
\hline \multirow{2}{*}{7} & \multirow{2}{*}{$0-1$} & $\mathrm{~A}$ & A-60 & 10 YR 2/2, Very dark brown & Lumpy \\
\hline & & (B) & $60-100$ & 2,5 YR 3/4, Dark reddish brown & Lumpy \\
\hline \multirow{2}{*}{8} & \multirow{2}{*}{$0-7$} & A & $0-51$ & 5 YR 3/2, Dark reddish brown & Lumpy \\
\hline & & $\mathrm{B}_{\mathrm{t}}$ & $51-80$ and over & 2,5 YR 3/6, Dark red & Lumpy to prismatic \\
\hline \multirow{2}{*}{9} & \multirow{2}{*}{$0-6$} & A & $0-60$ & 10 YR 2/2, Very dark brown & Lumpy \\
\hline & & (B) & $60-80$ and over & 2,5 YR 3/4, Dark red & Particulate \\
\hline
\end{tabular}

In general, the main soil genetic processes in these soils are: Brunification, Rubefaction and Rendzinification. The brunification is the process by which soil particulates take on a brownish coloring by goethite. During the process of the brunification, iron is released by altering the minerals. When this iron undergoes hydration in contact with water $\left(\mathrm{H}_{2} \mathrm{O}\right)$, this results in the formation of goethite (FeO-OH) (Benjelloun, 2017). The latter, by attaching itself to the soil particulates, gives them a brownish coloration (S1). This phenomenon occurs in temperate, Atlantic or semi-continental climates, distinguishing the class of browned 
soils under deciduous vegetation (Duchaufour, 1977) characterizing S1 where there is a mixed stand of zeen oak and green oak. The rubefaction is the phenomenon by which soil particulates take a reddish coloring by hematite $\left(\mathrm{Fe}_{2} \mathrm{O}_{3}\right)$ (Vandour, 1972). These are dehydration and oxidation of iron following evaporation in hot and dry Mediterranean-type climates (Duchafour, 1965). This is a characteristic of the soil class of iron sesquioxides (S2, S7, S8 and S9) (Table 3). The rendzinification is a set of processes leading to the formation of rendzina soil, a group of the calcimagnesic soil class. It consists in the formation of a stable complex between organic matter and calcium $\left(\mathrm{Ca}^{2+}\right)$ or a mantle out of this matter with active limestone $\left(\mathrm{CaCO}_{3}\right)$ which blocks any further evolution of organic matter and prevents its migration to depth, and consequently, we are witnessing the development of a soil with an organic horizon resting directly on the parent rock (Profile type A/CR) (Benjelloun, 2017). This is the case for S3, S4, S5 and S6 (Table 3).

Using the classification system adopted by the Commission of Pedology and Soil Mapping (CPCS, 1967), as well as the international system of classification, nomenclature and soil mapping used by FAO (2015), and based on the above data, the soils studied are classified as follows (Table 3, Figure2,3 and 4).

Table 3. Classification of the studied soils

\begin{tabular}{|c|c|c|c|c|c|}
\hline \multirow{2}{*}{$\begin{array}{l}\text { Classification } \\
\text { Number of } \\
\text { site }\end{array}$} & \multicolumn{4}{|c|}{ Commission on Pedology and Soil Mapping (1967) } & \multirow{2}{*}{$\begin{array}{r}\text { FAO - Word Reference } \\
\text { Base for soil ressources } \\
(\text { WRB })(2015)\end{array}$} \\
\hline & Class & Under class & Group & Under group & \\
\hline 1 & Browned & $\begin{array}{c}\text { Moist } \\
\text { temperate }\end{array}$ & Brown & Andic brown & Cambisols \\
\hline 2 & $\begin{array}{c}\text { Iron } \\
\text { sesquioxide }\end{array}$ & Fersialitic & $\begin{array}{c}\text { Without calcic reserve and } \\
\text { leached out }\end{array}$ & $\begin{array}{l}\text { With an andic } \\
\text { character }\end{array}$ & Nitisols-Alisols \\
\hline $3,4,5,6$ & Calcimagnesic & Carbonated & Rendzina & Modal & Leptosols \\
\hline 7 & $\begin{array}{c}\text { Iron } \\
\text { sesquioxide }\end{array}$ & Fersialitic & $\begin{array}{c}\text { Without calcic reserve and } \\
\text { leached out }\end{array}$ & $\begin{array}{l}\text { With an andic } \\
\text { character }\end{array}$ & \multirow{3}{*}{ Nitisols-Alisols } \\
\hline 8 & $\begin{array}{c}\text { Iron } \\
\text { sesquioxide }\end{array}$ & Fersialitic & $\begin{array}{c}\text { Without calcic reserve and } \\
\text { leached out }\end{array}$ & $\begin{array}{l}\text { With an andic } \\
\text { character }\end{array}$ & \\
\hline 9 & $\begin{array}{c}\text { Iron } \\
\text { sesquioxide }\end{array}$ & Fersialitic & $\begin{array}{c}\text { Without calcic reserve and } \\
\text { leached out }\end{array}$ & $\begin{array}{l}\text { With an andic } \\
\text { character }\end{array}$ & \\
\hline
\end{tabular}

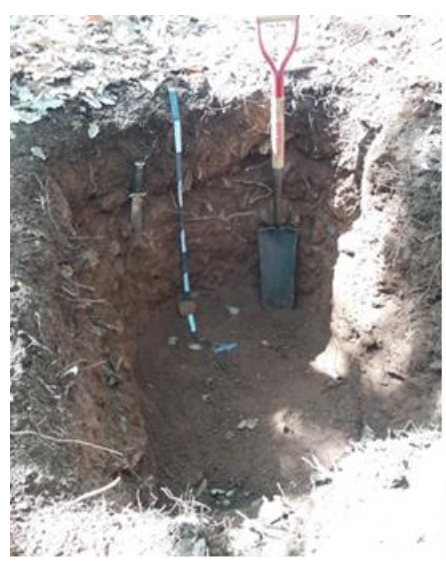

Figure 2. A profile of a browned soil

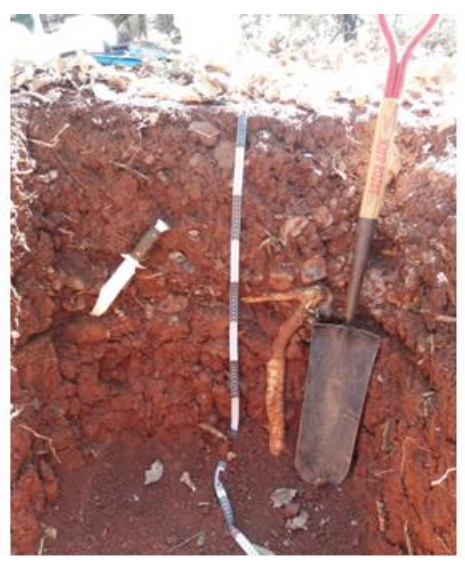

Figure 3. A profile of an iron sesquioxide soil

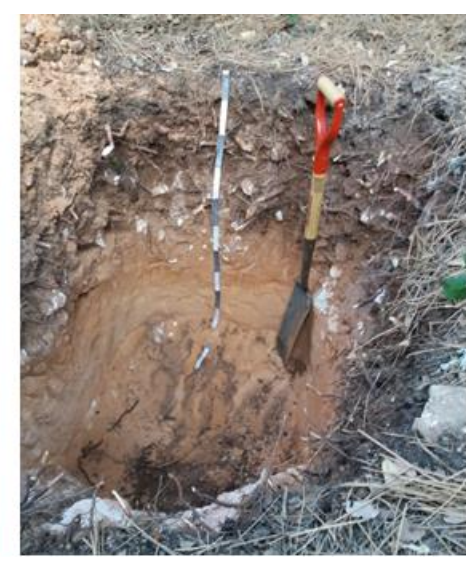

Figure 4. A profile of a calcimagnesic soil

\section{Physical and chemical characteristics}

\section{Granulometric composition and texture}

The granulometric analysis makes it possible to know (in weight form) the distribution of mineral soil particulates less than $2 \mathrm{~mm}$ according to size classes. A distinction is made between clays $(\varnothing \leq 2 \mu \mathrm{m})$, fine silts $(2 \mu \mathrm{m} \leq \emptyset \leq 20 \mu \mathrm{m})$, coarse silts $(20 \mu \mathrm{m} \leq \emptyset \leq 50 \mu \mathrm{m})$, fine sands $(50 \mu \mathrm{m} \leq \emptyset \leq 200 \mu \mathrm{m})$ and coarse sands $(200 \mu \mathrm{m} \leq \emptyset \leq 2000 \mu \mathrm{m})$. Texture plays an important role in porosity, drainage and especially carbon stocks in soils. It conditions soil structure and remains a reliable variable since it is stable and modified only according to long-term soil evolution (Gobat et al., 2003). By analyzing Table 4, the fractions of the studied soils (Sand, silt and clay) show some fluctuations within or across the same profile, with a dominance of the silt fraction, which has characterized the texture of these soils as determined from the textural triangle. The most represented textures are silty fine, silty clay and silty sandy.

The granulometric composition, an intrinsic characteristic of the soil, is little influenced by the vegetation cover (Benjelloun et al., 1997). As a result, the effect of different types of forest is not felt at this level. The effect of forest vegetation types is perceived in terms of chemical characteristics such as $\mathrm{pH}$, organic matter, nitrogen, $\mathrm{P}_{2} \mathrm{O}_{5}$ and exchangeable bases. 
Table 4. The granulometric composition of the studied soils

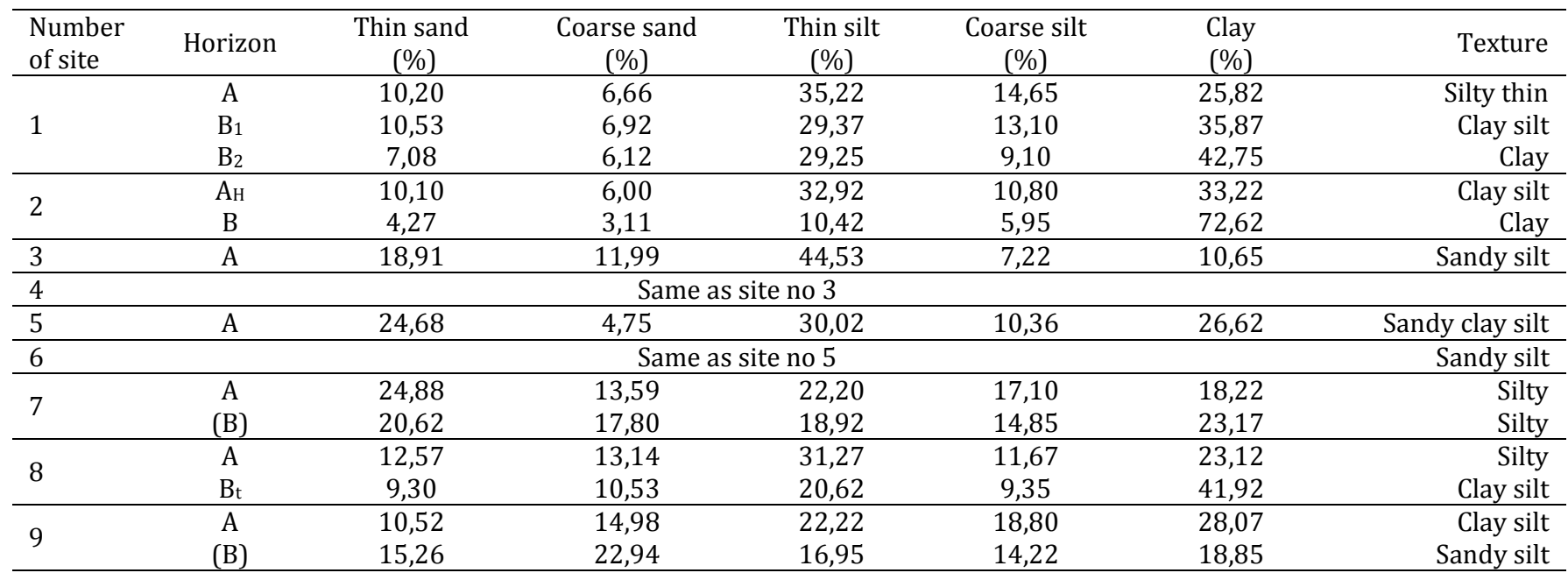

Soil chemical characteristics

The results of the analyses are grouped in Tables 5 and 6.

Table 5. The chemical characteristics of the studied soils

\begin{tabular}{|c|c|c|c|c|c|c|c|c|c|}
\hline $\begin{array}{l}\text { Number of } \\
\text { site }\end{array}$ & Horizon & $\mathrm{pH}$ н2о & $\mathrm{pH} \mathrm{ксl}$ & $\begin{array}{c}\text { Organic matter } \\
(\%)\end{array}$ & $\begin{array}{c}\text { Carbon } \\
(\%)\end{array}$ & $\begin{array}{c}\text { Total } \\
\text { Nitrogen (\%) }\end{array}$ & $\mathrm{C} / \mathrm{N}$ & $\begin{array}{c}\mathrm{P}_{2} \mathrm{O}_{5} \\
(\mathrm{mg} / \mathrm{kg})\end{array}$ & $\begin{array}{c}\mathrm{CaCO}_{3} \\
(\%) \\
\end{array}$ \\
\hline \multirow{3}{*}{1} & $\mathrm{~A}$ & 6,68 & 6,00 & 8,10 & 4,70 & 0,75 & 6,27 & 120,00 & 1,50 \\
\hline & $\mathrm{B}_{1}$ & 6,77 & 6,11 & 4,20 & 2,44 & 0,38 & 6,42 & 31,60 & 2,73 \\
\hline & $\mathrm{B}_{2}$ & 6,58 & 5,74 & 5,70 & 3,31 & 0,21 & 15,76 & 55,64 & 1,92 \\
\hline \multirow{2}{*}{2} & $\mathrm{~A}_{\mathrm{H}}$ & 6,82 & 6,10 & 7,00 & 4,06 & 0,17 & 23,88 & 52,22 & 0,60 \\
\hline & $\mathrm{B}$ & 6,56 & 6,54 & 4,00 & 2,32 & 0,05 & 46,40 & 17,86 & 0,70 \\
\hline 3 & A & 7,32 & 6,77 & 7,70 & 4,47 & 0,57 & 7,84 & 14,65 & 1,81 \\
\hline 4 & \multicolumn{9}{|c|}{ Same as site no 3} \\
\hline 5 & $\mathrm{~A}$ & 7,04 & 6,56 & 5,10 & 2,96 & 0,43 & 6,88 & 11,00 & 4,16 \\
\hline 6 & $\mathrm{~A}$ & 7,24 & 6,79 & 3,50 & 2,03 & 0,02 & 101,50 & 109,00 & 1,10 \\
\hline \multirow{2}{*}{7} & $\mathrm{~A}$ & 6,46 & 5,21 & 4,50 & 2,61 & 1,15 & 2,27 & 21,52 & 1,32 \\
\hline & (B) & 6,29 & 4,90 & 4,60 & 2,67 & 0,14 & 19,07 & 19,22 & 1,10 \\
\hline \multirow{2}{*}{8} & $\mathrm{~A}$ & 6,41 & 5,33 & 8,20 & 4,76 & 1,07 & 4,45 & 53,58 & 1,48 \\
\hline & $\mathrm{Bt}_{\mathrm{t}}$ & 6,33 & 4,74 & 6,00 & 3,48 & 0,05 & 69,60 & 38,47 & 2,57 \\
\hline \multirow{2}{*}{9} & $\mathrm{~A}$ & 6,41 & 5,43 & 7,40 & 4,29 & 1,62 & 2,65 & 174,00 & 1,97 \\
\hline & (B) & 6,33 & 4,8 & 4,40 & 2,55 & 0,37 & 6,89 & 18,77 & 1,36 \\
\hline
\end{tabular}

pH

The $\mathrm{pH}_{\mathrm{H} 20}$ analysis results (Table 5) show that the soils studied have $\mathrm{pH}$ values ranging from 6.3 to 7.3 (very weakly acidic to neutral). The $\mathrm{pH}_{\mathrm{KCl}}$ is always $11 \%$ to $33 \%$ lower than the $\mathrm{pH}_{\mathrm{H} 20}$. Indeed, the $\mathrm{pH}_{\mathrm{KCl}}$ indicates the quantity of $\mathrm{H}^{+}$protons in the soil solution as well as some or all of the $\mathrm{H}^{+}$ions on the adsorbent complex (acidity in reserve). The studied sites are divided into two groups, a first group where the soils are not very basic represented by the sites: S3, S4, S5 and S6. This can be explained on the one hand by the nature of the vegetation based on hardwood species (Green oak) for S3 and S6 (Duchaufour, 1977) and on the other hand by the presence of total limestone $\left(\mathrm{CaCO}_{3}\right)$ and the nature of the substrate which can explain the increase in pH in S4 and S5 despite the acidifying or low acidifying nature of the vegetation cover (cedar, maritime pine) (Duchaufour, 1965). Indeed, the presence of $\mathrm{CaCO}_{3}$ in addition to the exchangeable bases contributes to a saturation of the adsorbent complex and subsequently an increase in $\mathrm{pH}$. On the other hand, the soils of the second group tend to have lower $\mathrm{pH}$ : S1, S2, S7, S8 and S9. The acidification observed in this group is mainly due to the acidifying or slightly acidifying nature of the vegetation represented by resinous essences in their natural state (Duchaufour, 1977).

\section{Organic matter, carbon and nitrogen}

The chemical composition of soil organic matter $(\mathrm{OM})$ influences carbon and nutrient dynamics through the rapid degradation of its constituent substances (Banville, 2009). Plant composition is therefore the main factor responsible for differentiating the chemical properties of organic matter in soils (Banville, 2009). Good quality MO is more quickly eliminated by microorganisms and has a higher rate of decomposition. In general, the Mediterranean climate is not favorable for the accumulation of organic matter (Benjelloun et al., 1997). Generally, we perceive a drop in organic matter, carbon and nitrogen in the B horizon since the latter 
has a lower root density than the surface organic horizon where microbial activity is higher. In terms of fertility, and following these recorded values (Table 5), all sites are considered to be very rich in total nitrogen, values higher than $0.15 \%$ announced by Dabin (1963). The $\mathrm{C} / \mathrm{N}$ ratio can be used as an indicator of the organic matter decomposition rate and provides information on microbial activity in the soil. A high $\mathrm{C} / \mathrm{N}$ ratio represents a low rate of carbon decomposition since decomposing organisms use nitrogen which quickly becomes limiting (Benjelloun, 2002). Thus, for the surface horizons, and based on the soil reference frame (1995) cited in Ambassa (2005), the soils of the studied sites have active mineralization of organic compounds and present significant quantities of nitrogen allowing intense microbial activity and rapid decomposition of organic matter with the exception of S2 (Mix zen oak forest) whose $\mathrm{C} / \mathrm{N}$ ratio is higher $(23.88 \%)$, which indicates that the process of immobilization of nitrogen by microorganisms prevails over the process of mineralization.

Table 6. The chemical characteristics of the soils studied

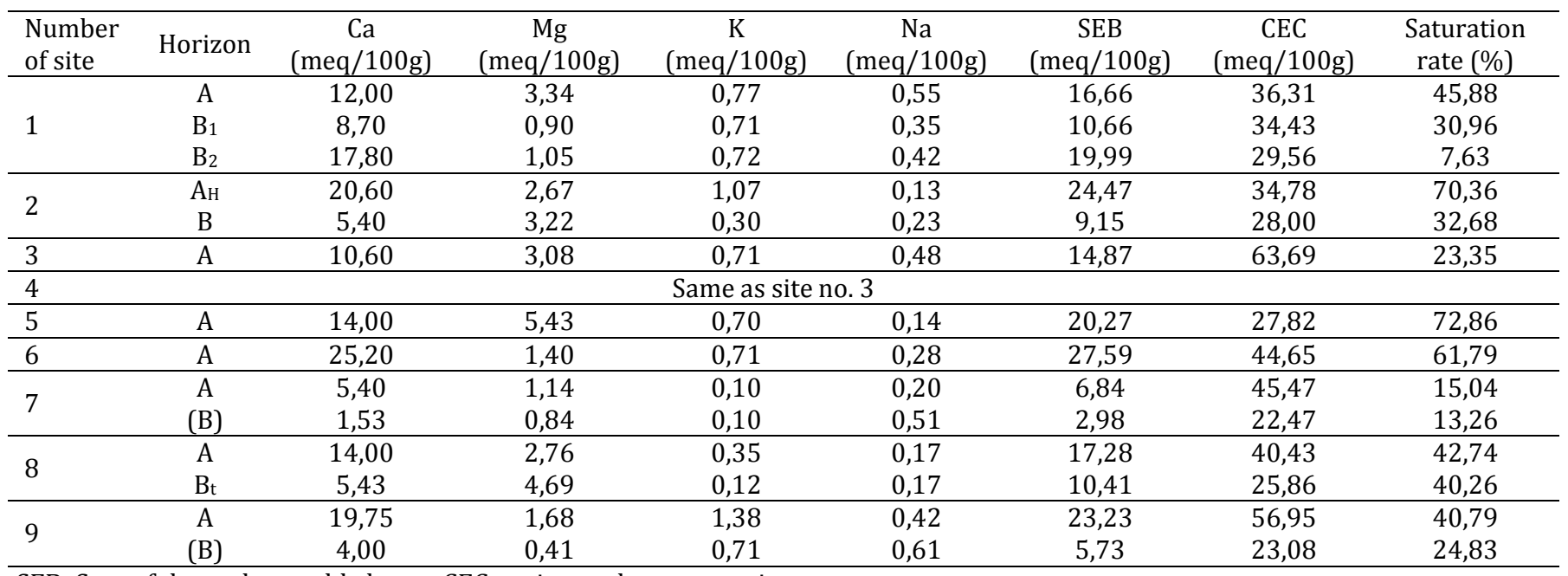

SEB: Sum of the exchangeable bases, CEC: cation exchange capacity

\section{The assimilable phosphorus $\mathrm{P}_{2} \mathrm{O}_{5}$}

The phosphorus cycle in the soil is a dynamic involving the soil, the plant, and the microorganisms. In soil, phosphorus can come either from carbonate rocks containing apatite or from acidic rocks containing variscite or strengite (Benjelloun et al., 1997). The values of assimilable posphorus in the studied areas show a poor to medium fertility level compared to the norms used by Bonneau (2001) in horizon A and shows a diminution with depth.

\section{Exchanged bases}

These are calcium, magnesium, potassium and sodium. Among these bases, calcium is the most important element in the studied soils (Table 6). In descending order, we find magnesium, then potassium and sodium. At the surface horizon, the sum of the exchanged bases (SEB) has the highest values under hardwood (green oak and zeen oak). The lowest value is found in S7 (pure Cedar). This is due to the great variability of the substrate but also to the acidity of the soils from the resinous species. Indeed, the reserves of nutrients present in soil minerals are depleted relatively faster under resinous species than under deciduous species (Augusto et al., 2000).

\section{Cation exchange capacity (CEC)}

The cation exchange capacity (CEC) of a soil is the maximum amount of cations that a soil can adsorb, in other words, this measure represents the total negative soil charges available for fixing $\mathrm{H}^{+}$and $\mathrm{Al}^{3+}$ ions and exchangeable bases. This parameter depends on colloids and soil $\mathrm{pH}$. Most of the studied soils have a high to very high CEC content due to the dominance of deciduous vegetation that improves the soil (Augusto et al., 2000) in the studied area.

\section{Conclusion}

The studied area is characterized by a sub-humid to humid climate with a very cold variant, a basaltic parent rock and sandy dolomite with an altitude varying between 1562 and $1768 \mathrm{~m}$. The forest formations encountered include resinous species based on cedar and maritime mountain pine, and other deciduous species as green oak and zeen oak. The morphological study and description of the genetic horizons of the studied soils allowed us to identify three types of soil characterizing the area, namely, the browned soil class, 
the iron sesquioxide soil class and the calcimagnesic soil class. This work shows that the chemical characteristics of the soils under study are influenced by the type of vegetation, in contrast to their intrinsic fertility properties.

\section{References}

Ambassa, B., 2005. L'étude comparative du stockage du carbone et de la minéralisation de l'azote dans les sols des forêts de chêne-liège et de résineux dans le bassin versant de Moulay Bouchta. Mémoire de fin d'études, 68p. [in French]

Augusto, L., Ranger, J., Bonneau, M., 2000. Influence des essences sur la fertilité chimique des sols. conséquences sur les choix sylvicoles. Revue Forestière Française 52(6): 507-518. [in French]

Banville, J.L., 2009. Caractérisation des stocks de carbone de 5 types de formations végétales dans un secteur du bassin versant de la rivière eastmain, baie james. Mémoire de maitrise. Université du québec. Montréal. Canada. 160p.

Benjelloun, H., 2002. Variabilité dans le temps et dans l'espace des formes minérales de l'azote dans les sols des écosystèmes forestiers du Moyen Atlas Central (Cas des forêts de Boujrirt et de Jaaba). Annales de la Recherche Forestière du Maroc 35: 31-42. [in French]

Benjelloun, H., 2017. Cours de pédologie forestière, 4ème année, INFI, Salé. Maroc. [in French]

Benjelloun, H., Zine El Abidine, A., Laghlam, A., 1997. Impact des différentes espèces de reboisement du chêne-liège et de l'absence du couvert végétal sur les propriétés physico-chimiques des sols dans la Mamora occidentale. Annales de la Recherche Forestière du Maroc 30: 17-31. [in French]

Bernoux, M., Cerri, C.C., Volkoff, B., Carvalho, M. C.S., Feller, C., Cerri, C.E.P., Eschenbrenner, V., Piccolo, M., C., Feigl, B, 2005. Gaz à effet de serre et stockage du carbone par les sols: Inventaire au niveau du Brésil. Cahiers Agriculture 14(1): 96-100. [in French]

Bonneau, M., 2001. Un siècle d'enseignement et de recherche en pédologie forestière. Revue Forestière Française 54(5): 585-603. [in French]

Chekol, W., Mnalku, A., 2012. Selected physical and chemical characteristics of soils of the middle awash irrigated farm lands, Ethiopia. Ethiopian Journal of Agricultural Sciences 22(1): 127-142.

Dabin, B., 1963. Appréciation des besoins en phosphore dans les sols tropicaux. Les formes de phosphore dans les sols de Cate d'Ivoire. Cah. ORSTOM, sér. Pédol. 3: 27-42. [in French]

Dabin, B., 1970. Les facteurs chimiques de la fertilité des sols (matière organique, phosphore). In : Ségalen Pierre, Dabin Bernard, Maignien Roger, Combeau André, Bachelier Georges, Schmid Maurice, Bosser Jean, Guinard M., Verdier P. Pédologie et développement. Paris : ORS TOM ; BDPA, (10), 191-219. (Techniques Rurales en Afrique ; 10).

Duchaufour, P., 1953. Etat actuel des connaissances sur la chimie de l'humus. Analyses de Brochures et Articles à l'Intention des Pédologues Travaillant dans les Territoires Tropicaux de l'Union Française 3(4): 1-3.

Duchaufour, P., 1965. Précis de pédologie. Masson, Paris, France. 481p. [in French]

Duchaufour, P., 1977. PEDOLOGIE 1. Pédogenèse et classification. Masson, Paris, France. 477p. [in French]

FAO, 2015. Les forêts et les sols forestiers: une contribution essentielle à la production agricole et à la sécurité alimentaire mondiale. Année internationale des sols. [in French]

FAO, 2017. Voluntary Guidelines for Sustainable Soil Management. Food and Agriculture Organization of the United Nations (FAO), Rome, Italy. 16p. Available at [Access date : 06.01.2018]: http://www.fao.org/3/a-bl813e.pdf

Gobat, J.M., Aragno, M., Matthey, W., 2003. Le sol vivant : Bases de pédologie, Biologie des sols. Presses polytechniques et universitaires romandes (Ed), 528p. [in French]

HCEFLCD., 2007. Etude d'aménagement concerté des forêts du Moyen Atlas. [in French]

Michard, A., 1976. Eléments de géologie marocaine. Notes et Mém. Serv. Carte géol. Maroc, 252, 408p. [in French]

Olsen, S.R., Sommers, L.E.,1982. Phosphorus. In: Methods of soil analysis. Part 2 Chemical and microbiological properties. $2^{\text {nd }}$ edition. Page, A.L. (Ed.). American Society of Agronomy, No. 9, Madison, WI, USA. pp. 403-430.

Olson, G.W., 1981. Soil and the environment. A Guide to Soil Survey sand their applications. Chapman and Hall, $178 \mathrm{p}$.

Onyekanne, C.F., Akamigbo, F.O., Nnaji, G.U., 2012. Characterization and classification of soils of Ideato North local government area. Nigerian Journal of Soil Science 22(1): 11-17.

Plaisance, G., Cailleux, A., 1958. Dictionnaire des sols. La maison rustique. Paris, 605 p. [in French]

Walkley, A., Black, C.A., 1934. An examination of Digestion method for determining soil organic matter and proposed modification of the chromic acid titration method. Soil Science 37(1): 29-38.

Watson, R.T., Rodge, H., Oesher, H., Siegenthaler, U., 1990. Greenhouse gases and aerosols. In: Climate change. Houghton, J.T., Jenkins, G.J., Ephraums, J.J. (Eds.). The IPCC Scientific Assessment. Cambridge University Press. New York, USA. pp. 5-50.

Wilke, B.M., 2005.Determination of chemical and physical soil properties. In: Manual of soil analysis: monitoring and assessing soil bioremediation. Margesin, R., Schinner, F., (Eds.). Vol 5, Springer-Verlag, Berlin, Heidelberg, pp.7982.

WRB., 2015. World reference base for soil resources 2014. International soil classification system for naming soils and creating legends for soil maps. Update 2015. Food and Agriculture Organization of The United Nations (FAO). World Soil Reported Resorces 106. Rome, Italy. Available at [Access date: 18.11.2018]: http://www.fao.org/3/i3794en/I3794en.pdf 